Research Article

\title{
Three-Delay Model on Maternal Mortality Cases in Tertiary Referral Hospital in Indonesia
}

\author{
Junita Indarti, ${ }^{*}$ Affan Solihin, Arresta V. Suastika, Dyah P. Wardhani, \\ Muhammad T. Ramadhani, Quamila F. Afdi, Syifa M. Syafitri, \\ Muhammad Ikhsan, Kristian Alda
}

Department of Obstetrics and Gynecology, Faculty of Medicine Universitas Indonesiadr. Cipto Mangunkusumo National General Hospital, Jakarta ${ }^{*}$ Corresponding author: junitaindarti@gmail.com
Received 10 June 2020; Accepted 17 August 2021
https://doi.org/10.23886/ejki.9.60.99

\begin{abstract}
Maternal mortality remains a worldwide concern to this day. Three main causes of maternal mortality during 2010-2013 were hemorrhage, hypertension, and infection, which all of them are the direct causes. The high MMR is also due to the presence of 3 delay which is Delay in seeking assistance (type-1), delay in identifying and accessing medical center (type-2) and delay in having prompt treatment (type-3) . Therefore, this study aims to describe maternal mortality cases in tertiary hospital which is Cipto Mangunkusumo Hospital (CMH) so that the root of problems in maternal deaths can be discovered and improvements can be done in the future. This was a descriptive study conducted in the Department of Obstetrics and Gynecology at CMH, Jakarta. Data collection was taken from 2016 - 2018 where subjects were taken from secondary data on maternal mortality. Based on the data that has been collected in $\mathrm{CMH}$ total live births in Emergency Department CMH during 2016-2018 which was 4.226 cases. There was 22 maternal death cases (0.52\%). Most deaths were occurred in 2017 (50\% of all cases). Indirect causes of maternal mortality were the leading cause in this study, including septic shock, hypovolemic shock due to Dengue Shock Syndrome, cardiogenic shock, and acute respiratory failure. Three delay models were three main factors contributing to maternal mortality interrelated and influenced by other factors with delay in looking for assistance and treatment $(31,8 \%)$ was the upmost factor of maternal mortality. More than half maternal deaths in CMH during 2016 - 2018 caused by indirect causes. Among three delay models, delay in looking for assistance and treatment was the upmost factor of maternal mortality.
\end{abstract}

Keywords: maternal mortality, three-delay model.

\section{Tiga Model Keterlambatan pada Kasus Kematian Ibu di Rumah Sakit Tersier di Indonesia}

\begin{abstract}
Abstrak
Kematian ibu masih menjadi perhatian dunia hingga saat ini. Tiga penyebab utama angka kematian ibu (AKI) selama 2010-2013 adalah perdarahan, hipertensi, dan infeksi, yang semuanya merupakan penyebab langsung. Tingginya AKI juga disebabkan oleh adanya 3 keterlambatan yaitu keterlambatan dalam mencari pertolongan, keterlambatan dalam mengidentifikasi dan mengakses pusat kesehatan, dan keterlambatan dalam mendapatkan pengobatan yang tepat. Penelitian ini bertujuan untuk mendeskripsikan kasus kematian ibu di rumah sakit tersier yaitu Rumah Sakit Cipto Mangunkusumo (RSCM) sehingga akar permasalahan kematian ibu dapat ditemukan dan dapat dilakukan perbaikan di masa yang akan datang. Penelitian ini merupakan penelitian deskriptif yang dilakukan di Bagian Obstetri dan Ginekologi RSCM, Jakarta. Pengambilan data diambil dari tahun 2016 - 2018, subjek diambil dari data sekunder kematian ibu. Berdasarkan data yang terkumpul di RSCM jumlah kelahiran hidup di Instalasi Gawat Darurat RSCM selama tahun 2016-2018 sebanyak 4.226 kasus. Terdapat 22 kasus kematian ibu (0,52\%). Kematian terbanyak terjadi pada tahun 2017 (50\% dari seluruh kasus). Penyebab tidak langsung kematian ibu merupakan penyebab utama dalam penelitian ini, antara lain syok septik, syok hipovolemik akibat dengue shock syndrome, syok kardiogenik, dan gagal napas akut. Tiga model keterlambatan merupakan tiga faktor utama penyebab kematian ibu yang saling berkaitan dan dipengaruhi oleh faktor lain dengan keterlambatan mencari pertolongan dan pengobatan (31,8\%) merupakan faktor penyebab kematian ibu yang paling tinggi. Lebih dari separuh kematian ibu di RSCM selama tahun 2016 - 2018 disebabkan oleh penyebab tidak langsung. Di antara tiga model keterlambatan, keterlambatan dalam mencari bantuan dan pengobatan merupakan faktor utama kematian ibu.
\end{abstract}

Kata kunci: kematian maternal, model tiga terlambat. 


\section{Introduction}

MMR useful to measure public health degree despite of maternal health program, because of its sensitivity to improving health services, both in terms of accessibility and quality. ${ }^{1}$ Based on Maternal Health Directory data, Ministry of Health Republic of Indonesia in 2014, three main causes of maternal mortality during 2010-2013 were hemorrhage, hypertension, and infection, which all of them are the direct causes. ${ }^{2}$ Similar causes has been reported by World Health Organization (WHO) as Asia's main causes of maternal deaths. ${ }^{3}$ In addition to direct causes, there are also factors that cause high MMR, among others, are three factors of delay.

Three delay models were three main factors contributing to maternal mortality interrelated and influenced by other factors. Delay in seeking assistance (type-1) influenced by level of education, cultural beliefs, and economic status both mother and her family. Delay in identifying and accessing medical center (type-2) influenced by transportation difficulties and inadequate referral facility. Delay in having prompt treatment (type3 ) influenced by disease progressiveness and inadequate treatment.

Cipto Mangunkusumo Hospital (CMH) as tertiary health care facility is the main referral site for maternal cases from Jakarta even from the whole country. Fernando et $\mathrm{al}^{4}$ reported 159 maternal deaths in $\mathrm{CMH}$ during January 2008-December 2016 which equals 661 deaths per 100.000 live births. There has been a significant reduction in maternal deaths in 2008-2016, from 22 deaths in 2008 to 13 deaths in 2016. Nevertheless, the mean value was still higher than national MMR because $\mathrm{CMH}$ is the main referral cite from all over Indonesia, so there were complicated cases that could not be handled by primary and secondary health care facility. Mishandling from primary and secondary health care facility and delay in referring process contribute to high maternal mortality in tertiary hospital. ${ }^{5}$

Based on the problem stated above, this study aims to describe maternal mortality cases in tertiary hospital which is $\mathrm{CMH}$ so that the root of problems in maternal deaths can be discovered and improvements can be done in the future.

\section{Methods}

This was a descriptive retrospective study conducted in the Department of Obstetrics and Gynecology at $\mathrm{CMH}$, Jakarta and data collection was taken from 2016 to 2018 . The target population of the study was maternal deaths that occurred in $\mathrm{CMH}$ and subjects were taken from secondary data using consecutive method. Inclusion criteria were pregnant and postpartum woman who died in $\mathrm{CMH}$ and exclusion criteria was patients who died on the trip during the referral process. All maternal mortality cases were collected and analyzed by grouping them into three criteria of three delay model. Delay in seeking assistance (type-1) influenced by level of education, cultural beliefs, and economic status both mother and her family. Delay in identifying and accessing medical center (type-2) influenced by transportation difficulties and inadequate referral facility. Delay in having prompt treatment (type-3) influenced by disease progressiveness and inadequate treatment. We also conclude risk factor which consist age, parity, marital status, gestational age and referral. Study had been approved by Ethical Committee of Faculty of Medicine Universitas Indonesia - CMH Number: KET-532/UN2.F1/ETIK/PPM.00.02/2019

\section{Results}

Based on the data that has been collected in $\mathrm{CMH}$ total live births in Emergency Department $\mathrm{CMH}$ during 2016-2018 which was 4.226 cases. There was 22 maternal death cases $(0.52 \%)$. (Table 1$)$.

Table 1. Maternal Deaths in CMH in 2016 - 2018

\begin{tabular}{cccc}
\hline Year & $\begin{array}{c}\text { Maternal } \\
\text { Deaths }(\mathbf{n})\end{array}$ & $\begin{array}{c}\text { Live } \\
\text { Births }(\mathbf{n})\end{array}$ & $\%$ \\
\hline 2016 & 7 & 1.714 & 0.41 \\
2017 & 11 & 1.475 & 0.75 \\
2018 & 4 & 1.037 & 0.39 \\
Total & 22 & 4.226 & 0.52 \\
\hline
\end{tabular}

Most deaths were occurred in 2017 (50\% of all cases) and between age 31-35 years old, which was $32 \%$. There were $77 \%$ maternal deaths that occurred to the pregnant woman. The third trimester is the most common trimester (54\%). Moreover, $77.2 \%$ cases were occurred in multiparity women (2-4 parities) and $77 \%$ cases were referral cases. The risk factor of maternal deaths during 20162018 were illustrated in Table 2. 
Table 2. Risk Factor of Maternal Deaths in CMH, 2016-2018

\begin{tabular}{lcc}
\hline Risk Factor & $\mathbf{n}$ & $\%$ \\
\hline Age (years old) & & \\
$16-20$ & 1 & 4.5 \\
$21-25$ & 3 & 13.6 \\
$31-35$ & 7 & 32.0 \\
$36-40$ & 5 & 22.7 \\
$>40$ & 6 & 27.2 \\
Parity & & \\
1 & 3 & 13.6 \\
$2-4$ & 17 & 77.2 \\
$>4$ & 2 & 9.2 \\
Maternity Status & & \\
Pregnant & 17 & 77.0 \\
Post pregnancy & 5 & 23.0 \\
Gestational Age (trimester) & & \\
1 & 0 & 0 \\
2 & 5 & 23.0 \\
3 & 12 & 54.0 \\
Postpartum & 5 & 23.0 \\
Referral & & \\
Yes & 17 & 77.0 \\
No & 5 & 23.0 \\
\hline
\end{tabular}

Table 3 showed that indirect causes were the leading cause. The indirect causes $(50 \%)$ including septic shock (6 cases), cardiogenic shock ( 2 cases), hypovolemic shock due to dengue shock syndrome, and acute respiratory failure. Direct causes of maternal death were mostly caused by complications of unanticipated treatment. In our study 3 cases complications of unanticipated treatment occurred on PPH. Coincidental was deaths from unrelated causes which happen to occur in pregnancy or the puerperium. We have 2 cases which is sepsis cause of Ventilator Acquired Pneumonia and Respiratory Failure cause of Myelitis.

Table 3. Causes of Maternal Death in CMH, 2016 - 2018 Based on WHO

\begin{tabular}{lc}
\hline Causes & $\mathbf{n}$ \\
\hline Direct & \\
$\quad$ Pregnancy (not including miscarriage) & 0 \\
$\quad$ Hypertension in pregnancy, delivery and & $2 / 22$ \\
postpartum & $2 / 22$ \\
$\quad$ Obstetric hemorrhage & $1 / 22$ \\
$\quad$ Pregnancy with infection & $1 / 22$ \\
$\quad$ Other obstetric complication & $3 / 22$ \\
$\quad$ Complications of unanticipated treatment & \\
Indirect & $11 / 22$ \\
$\quad$ Non obstetric complications & \\
Unspecified & 0 \\
$\quad$ Other uncategorized complications & $2 / 22$ \\
Coincidental & \\
$\quad$ External causes of deaths in pregnancy, \\
$\quad$ delivery, and postpartum
\end{tabular}

Classification of the cases were centered on the three delay model. It was divided to single cause and multiple causes, because the delay factors were multifactorial. From this data, a delay in looking for assistance and treatment happened in 7 cases from 22 maternal death $(31.8 \%)$ was the upmost factor of maternal mortality in the three delay model (Table 4).

Table 4. Classification of Delay Based on the Three Delay Model

\begin{tabular}{lc}
\hline Classification of Delay & $\mathbf{n}$ \\
\hline Seeking assistance & $4 / 22$ \\
Identifying and accessing medical center & 0 \\
Having prompt treatment & $6 / 22$ \\
$\begin{array}{l}\text { Seeking assistance, identifying and accessing } \\
\text { medical center }\end{array}$ & 0 \\
$\begin{array}{l}\text { Seeking assistance and having prompt } \\
\text { treatment }\end{array}$ & $7 / 22$ \\
$\begin{array}{l}\text { ldentifying, accessing medical center, and } \\
\text { having prompt treatment }\end{array}$ & 0 \\
$\begin{array}{l}\text { Seeking assistance, identifying, accessing } \\
\text { medical center, and having prompt treatment }\end{array}$ & $5 / 22$ \\
\hline
\end{tabular}

\section{Discussion}

Maternal mortality remains a worldwide concern to this day. Maternal mortality rate (MMR) is one of Millennium Development Goals (MDGs) indicators to improve mothers health. ${ }^{1}$ There has been a remarkable decline in Indonesia's MMR, which is 390 deaths per 100.000 live births in 1991 to 305 deaths per 100.000 live births in 2015 . However, this value has not reach the MDGs target yet, which is 102 deaths per 100.000 live births in 2015. ${ }^{1}$

Maternal mortality cases in $\mathrm{CMH}$ mostly occurred in 2017, which were 11 cases and $0.75 \%$ of all live births in that year. The total of maternal deaths in $\mathrm{CMH} 2016$ - 2018 were 22 cases, with the total of live births were $4.226(0.52 \%)$. As we can compare from other countries, Nepal reported 66 maternal deaths with 192.487 total births $(0.03 \%)$ for the last 10 years (2002-2011) in tertiary hospital. ${ }^{7}$ In West Mahrashtra, India reported 120 maternal deaths with 39.704 total births $(0.30 \%)$ for the last 10 years (2001-2010) in tertiary hospital. Same studies in Udupi and Karnataka, India reported 23 maternal deaths with 7.330 live births $(0.31 \%)$ from January 2011 until December 2012. ${ }^{8}$

From all of the 22 maternal mortality cases that occurred in 2016-2018 in $\mathrm{CMH}, 17$ cases (77\%) were referral cases. The main cause of maternal mortality is delay in seeking assistance and having 
prompt treatment. Most of the referral cases, some of them refused to seek assistance because they were unable to recognize the warning signs, and lack of education from the mothers and family. In addition, inadequate treatment in the primary health care leads to progressivity of the disease. It explains why maternal mortality cases were mostly found in referral cases.

A retrospective cohort study in RSUP Dr. Sardjito, Yogyakarta, compared the quality of maternal service between death cases and near miss cases in $2017 .{ }^{9}$ There were 114 cases consist of 28 cases of maternal deaths and 86 near miss cases. The previous study had a similar percentage with this current study; maternal mortality cases were mainly found in referral cases. Among 28 cases, 23 cases $(88.46 \%)$ were originated from referral cases. Severe preeclampsia was the most common diagnosis, 17 cases were found $(60.7 \%)$. The factor that distinguish maternal mortality and near miss cases is delay in initiating treatment, including obstetric resident response time, and ICU waiting time. ${ }^{9}$

A multicenter study about prevalence and risk factors for maternal mortality in 8 referral hospitals in Nigeria in 2018 reported similar result. ${ }^{10}$ Over 6 months, maternal mortality rate was 2.085 per 100.000 live births. High MMRs were found in 8 hospitals because these hospitals are designated to receive and manage obstetric referrals from primary health care settings and also to deal with severe complications of pregnancy. Several factors were identified in this study as likelihood of maternal mortality. These include non-booking for antenatal care, referral from lower level health/nonhealth facilities with complicated cases. Several factors have been reported as reducing women's access to antenatal, delivery, emergency obstetric and postnatal care in various parts of the country. These include inability to pay services, perceptions relating to unfriendly health providers, cultural beliefs, and difficulty with transportation.

Maternal deaths are subdivided into two groups direct and indirect. Direct obstetric deaths are those resulting from obstetric complications of the pregnancy state (pregnancy, labor, and the purpureal), from interventions, omissions, incorrect treatment, or from a chain of events resulting from any of the above. Indirect obstetric deaths are those resulting from previous existing disease or disease that developed during pregnancy and which was not due to direct obstetric causes, but which was aggravated by physiologic effects of pregnancy. ${ }^{11}$
In 2015, WHO reported the most cases of maternal deaths was hemorrhage (27\%). However, similar percentage was also found in indirect causes (28\%).

Compared to $\mathrm{WHO}$ data about maternal mortality causes globally, percentage of the highest maternal mortality number in $\mathrm{CMH}$ in $2016-2018$ was similar; the main cause of maternal mortality is indirect causes (50\%). The indirect causes were mostly by sepsis, hypovolemic shock due to dengue shock syndrome, cardiogenic shock, and acute respiratory failure. The direct causes of maternal mortality were mainly postpartum hemorrhage, which was the complication of unanticipated treatment. One of the underlying reasons of indirect causes of maternal deaths were commonly found rather than the direct causes in $\mathrm{CMH}$ during 20162018, it was due to disease progressivity were dominated by indirect causes of deaths. Moreover, $\mathrm{CMH}$ is a tertiary hospital that receive a wide range of referral cases.

There is a difference in main cause of maternal mortality between Pusat Kesehatan dan Informasi Kemenkes in 2014 and this study. ${ }^{12}$ The main cause of maternal deaths according to this data is hemorrhage (30.3\% in 2013) and hypertension (27.1\% in 2013) throughout Indonesia. The reason this study has different main cause of maternal mortality comparing to Pusat Kesehatan dan Informasi Kemenkes because we only receive data from tertiary hospital (CMH).

Another study in Rwanda in 2015 which discuss the prevalence and factor related to maternal mortality in tertiary hospitals stated three main causes of maternal deaths are peritonitis and sepsis $(28 \%)$, hemorrhage $(22 \%)$, and severe preeclampsia $(16 \%) .{ }^{13}$ The high prevalence of peritonitis may reflect a lack of experience, since the doctors working in district hospitals may be recent medical school graduates who have not completed residency programs. They may also reflect unsterile techniques and proper antibiotics usage. Obstetric hemorrhage was among the leading causes of severe obstetric morbidity and mortality. However, hemorrhage was not the leading cause of maternal death. This finding may represent education and aggressive, standard management of obstetric hemorrhage. In Rwanda, care providers in tertiary hospitals are well trained in the prevention and management of obstetric hemorrhage.

Retrospective study in RSUP Dr. Sardjito, which was a tertiary hospital also have a similar result in the main cause of maternal mortality. ${ }^{9}$ The 
most cases of maternal deaths was sepsis $(60.7 \%)$. However, they cannot explain why sepsis became the most cause of maternal death.

Three delay models have a big role in the occurrence of maternal deaths. The first is delay in seeking assistance, including ability to recognize emergency situation so mothers could be referred to higher level of health care facility when complication occurs. The second delay occurs after decision to be referred was made, is identifying and accessing medical center, including geographic and transportation difficulties followed by the third delay, having prompt treatment.

Three delay models are multifactorial which consist of socio-economy, infrastructure, and quality of service. In our study, the most influential factor contributing to maternal death is combination between delay in seeking assistance and delay in having prompt treatment $(31.8 \%)$. Mothers and family inability to recognize emergency situation caused by low level of education become one of the reasons why someone having a delay in seeking assistance. Economic conditions are less influential because of JKN system. Delay in having prompt treatment mostly due to disease progressivity leading to complications. Majority of patients came with multiple organ dysfunctions because of delay in seeking assistance. Inadequate treatment from primary level of healthcare also became root of delay in seeking assistance and having prompt treatment.

Delay in identifying and accessing medical center was not found in this study. Easy transportation access become one of the reason second type of delay was not occur. Besides, all of the cases were come from the same city as $\mathrm{CMH}$.

Five cases $(22.9 \%)$ were found having all three type of delay. Among these 5 cases, delay in seeking assistance was due to inadequate treatment from lower health care facility. Delayed in identifying and accessing medical center, all of the five cases were having inadequate referral facility. Two types of delay above lead to third type of delay caused by disease progressiveness. Three delay model relate to one another that involved various factors.

A case control study in Cilacap in 2010 which aim to discover role of three delay models in maternal mortality compared between case and control group. Result of this research showed that type -1 delay (seeking assistance) correlate to maternal death $(p<0.001)$ with $O R=16,429$. Mother who experienced type-1 delay has a 16 times greater chance of dying. Bivariate analysis showed delay on arriving in referral hospital related to maternal death $(\mathrm{OR}=5,091)$. It means, mother will have 5 times greater chance of dying if they experienced type-2 delay. Type-3 delay was not statistically significant.

Comparing to study in Cilacap, our study has dissimilarity in role of three delay models. This is reflected by Cilacap geographical condition which allows type-2 delay to occurr more frequently. Distance in reaching hospital, damaged road conditions that leads to slow pace of transportation, become main reason of type-2 delay in Cilacap.

A similar study in Malawi, 2017 about factors associated with maternal mortality and application of the three delay models. ${ }^{14}$ There were 151 maternal death during one year. Among 151 cases, type-3 delays were the most frequently encountered and were identified in $96.8 \%$ of all maternal deaths. Contributing factors included long waiting times before receiving any type of assessment or treatment at a healthcare facility, non-availability of essential drugs, lack of skilled personnel, missed and incorrect diagnosis, and delayed or incorrect treatment.

Background was found to be distinguishing factor between our study and research in Malawi. ${ }^{14}$ Health system failures in third world country have been identified as a major contributing factor to maternal deaths and the delay in or inability to ensure timely referral was noted in Malawi. Lack of antibiotics, magnesium sulfate and lack of blood in the blood bank were also found.

\section{Conclusions}

There were 22 maternal deaths from 4.226 $(0.52 \%)$ live births at the $\mathrm{CMH}$. More than half maternal deaths in $\mathrm{CMH}$ during 2016 - 2018 caused by indirect causes (50\%). The combination of delay in seeking assistance and delay in having prompt treatment was the most common factor in $\mathrm{CMH}$ during 2016 - 2018 contributing to maternal deaths. Among 22 maternal mortality cases, type-2 delay was not found as a single factor contributing to maternal death. This is due to no significant transportation difficulties to reach $\mathrm{CMH}$.

\section{References}

1. Profil Kesehatan Indonesia Tahun 2017. Jakarta: Kementerian Kesehatan RI; 2017.

2. Pusat Data dan Informasi. Jakarta: Kementerian Kesehatan RI; 2014

3. Say L, Chou D, Gemmill A, Tunçalp Ö, MollerA, Daniels $J$, et al. Global causes of maternal death: a WHO systematic analysis. Lancet Glob Heal. 2014;2(6):e32333. doi: 10.1016/S2214-109X(14)70227-X. 
4. Fernando D, Ocviyanti D. Telaah kualitas asuhan antenatal pada kasus dengan kematian maternal di Rumah Sakit dr. Cipto Mangunkusumo [Master's Thesis]. Jakarta: Universitas Indonesia; 2017.

5. Pandey A, Das V, Agarwal A, Agrawal S, Misra D, Jaiswal N. Evaluation of obstetric near miss and maternal deaths in a tertiary care hospital in north India: shifting focus from mortality to morbidity. J Obstet Gynaecol India. 2014;64:394-9. doi: 10.1007/ s13224-014-0552-1.

6. BPJS Kesehatan. Panduan praktis tentang kepesertaan dan pelayanan kesehatan yang diselenggarakan oleh BPJS Kesehatan berdasarkan regulasi yang sudah terbit. Jakarta: BPJS; 2014.

7. Upadhyaya I. Maternal death reviews at a tertiary care hospital. J Nepal Med Assoc. 2014;52:713-8.

8. PSR, VermaS, RaiL, KumarP,PaiM,ShettyJ."NearMiss" obstetric events and maternal deaths in a tertiary care hospital: an audit. J Pregnancy. 2013;2013:393758. doi: $10.1155 / 2013 / 393758$.

9. Mawarti $Y$, Utarini A, Hakimi M. Maternal care quality in near miss and maternal mortality in an academic public tertiary hospital in Yogyakarta, Indonesia: a retrospective cohort study. BMC Pregnancy Childbirth. 2017;17:149. doi: 10.1186/s12884-017-1326-4.
10. Ntoimo L, Okonofua F, Ogu R, Galadanci H, Gana $\mathrm{M}$, Okike $\mathrm{O}$ et al. Prevalence and risk factors for maternal mortality in referral hospitals in Nigeria: a multicenter study. Int J Womens Health. 2018;10:6976. doi: 10.2147/IJWH.S151784.

11. Geneva WHO. The WHO Application of ICD-10 to deaths during pregnancy, childbirth and the puerperium: ICD-MM [Internet]. Geneve: WHO; 2012. Available from: http://apps.who.int/iris/ bitstream/10665/70929/1/9789241548458_eng. pdf?ua=1

12. Kematian ibu dan upaya-upaya penanggulangannya | PKBI [Internet]. Pkbi.or.id. 2019 [cited 8 May 2019]. Available from https://pkbi.or.id/kematian-ibu-danupaya-upaya-penanggulangannya/

13. Rulisa S, Umuziranenge I, Small M, van Roosmalen J. Maternal near miss and mortality in a tertiary care hospital in Rwanda. BMC Pregnancy Childbirth. 2015;15:203. doi: 10.1186/s12884-015-0619-8.

14. Mgawadere F, Unkels R, Kazembe A, van den Broek $\mathrm{N}$. Factors associated with maternal mortality in Malawi: application of the three delays model. BMC Pregnancy Childbirth. 2017;17(1):219. doi: 10.1186/ s12884-017-1406-5.. 